\title{
Grasp Reflex
}

National Cancer Institute

\section{Source}

National Cancer Institute. Grasp Reflex. NCI Thesaurus. Code C81254.

An involuntary, primal response in the neonate to grasp the fingers when their palm is touched. This reflex is present until six months of age. 